Bangladesh J. Bot. 48(4): 1133-1142, 2019 (December)

\title{
A COMPARATIVE STUDY OF YIELD AND QUALITY OF LOCAL KARACADAG AND OSMANCIK-97 IN CONVENTIONAL AND ORGANIC AGRICULTURAL CONDITIONS
}

\author{
Şerif Kahraman ANd Aydin Alp ${ }^{1^{*}}$ \\ GAP International Agricultural Research and Training Centre, Diyarbakır, Turkey
}

Keywords: Karacadag, Osmanc1k-97, Rice, Yield, Organic agricultural condition, Conventional agriculture

\begin{abstract}
The work was carried out to compare the yield and quality of local Karacadag rice variety with the Osmancik-97 in conventional and organic agriculture conditions. In the organic agricultural conditions higher values were obtained compared to conventional conditions. Flowering took 82.6 days, 1000-kernel weight $(31.38 \mathrm{~g})$ and non-fractured rice yield were $61.75 \%$. Local Karacadag rice variety under the organic conditions showed significantly higher values compared to Osmancik-97 breeding variety took 87.3 days for flowering, 128.2 days for ripening days. Plant height $(84.1 \mathrm{~cm})$, number of tillering in plants $(2.82)$, number of bunches in the $\mathrm{m}^{2}$ (369.3), kernel number of bunch (56.5), bunch length $(15.9 \mathrm{~cm})$, biological yield (13440 $\mathrm{kg} / \mathrm{ha})$, yield for unit area $(4681 \mathrm{~kg} / \mathrm{ha})$ and non-fractured rice yield $(64.7 \%)$ were observed. While there was no difference between the two rice varieties with regards to the kernel weight of bunch. Local Karacadag variety proved its ability to adapt to the ecological conditions of the region. It is suggested that the cultivation of the Karacadag rice cultivar in organic agriculture conditions may be expanded in the region.
\end{abstract}

\section{Introduction}

Rice is an important cereal type which is used as food for human nutrition. The world's cereal production is 769.6 million tons and it ranks third after the corn and wheat production (Anon. 2017). According to the data in 2017, the countries where rice cultivation intensively carried out were: 214 million tons with China, 168.5 million tons in India, 81.4 million tons in Indonesia, 49 million tons in Bangladesh, 42.7 million tons in Vietnam. Seventy per cent of total rice production in the world is carried out in these countries (Anon. 2017).

Although the share of the organic agriculture and its food products in the worlds is small (1 $4 \%$ ), it shows a rapid development trend over the years. The trade volume of organic products increased 1.3 times between 1996 and 2000, reaching 21.5 billion dollars (Demiryürek 2004). According to the agricultural statistics, there were approximately 37.2 million hectares of organic farming area in 160 countries in the world in 2009. These areas constitute only $0.9 \%$ of the total agricultural land in the world (Willer and Klicher 2011).

Although the rice cultivation area in Turkey shows fluctuations from year to year, it was 109 505 hectares total production was 900000 tons and the yield was $8218 \mathrm{~kg} / \mathrm{ha}$ in 2017 (Anon. 2017). Rapid population growth and the difficulty of sowing in certain areas limited rice production by making imports inevitable. There are about 40 provinces in the Turkey where rice is cultivated. Some of them are 386907 tons with Edirne, 122600 tons with Samsun, 113994 tons with Balıkesir, 91880 tons with Çanakkale and 52298 tons with Çorum. The rice production in the country cannot meet her needs (Anon. 2015).

*Author for correspondence: <aydinalp21@hotmail.com>. ${ }^{1}$ Department of Field Crops, Faculty of Agriculture, Dicle University. Diyarbakır, Turkey. 
In the south-east Anatolia region, rice cultivation is 2356 ha, production is 11250 tons and the yield is $4770 \mathrm{~kg} / \mathrm{ha}$. All of the rice production in the region takes place in Diyarbakır and Şanlıurfa provinces. The total area of rice cultivation in Diyarbakır is 1747 ha with 8514 tons of production and in Şanliurfa the cultivated area is 608 ha with 2736 tons of production (Anon. 2015). Local Karacadag variety grows in the entire rice area in the Diyarbakır.

Organic farming is known as aiming at re-establishing the natural balance that is lost after the erroneous and excessive application in the production system, the prohibition of the use of synthetic chemical medicines and fertilizers which include human and environmentally friendly production systems; organic and green fertilization, alternation, conservation of soil, increasing the resistance of the plant, a system which recommend to take advantage of the natural enemies of the pests and it is a production type aiming at increasing the quality of the product rather than its quantity (Altındişli and İlter 1999).

Organic agriculture, a form of agricultural production that protects human and environmental health, including the use of natural substances and methods instead of synthetic chemical pesticides and mineral fertilizers, has been gradually increasing in recent years in the world and in the Turkey as a result of conventional agricultural practices (İnci and Sönmez 2006).

The south-east Anatolia region has a considerable potential for organic agriculture production when taking into consideration the surplus of agricultural population, climate and soil structure of the area (Gürsoy et al. 2009). With the south-east Anatolia Project (GAP), an irrigation water deficiency which is the biggest bottleneck in the rice farming will be eliminated largely. The soil of the region has not been contaminated with excessive fertilizers and chemicals. As the soil is fertile, productivity can be achieved at low costs in agricultural production. The Karacadag rice variety is the reason for the success of the critical years with bad environmental conditions as well as its quality characteristics that meet the local consumers' demands.

The Karacadag rice is a high quality local variety that adapts to the ecological conditions of the region (the fact that the region has adapted to the special soil structure and irrigation water distinguishes paddy product from the other varieties). The most important feature of the Karacadag rice variety is its good colour, flavour and taste. The ability of its kernels to draw water during cooking is high. It does not have lapping and stickiness properties. Its shape and size are also important distinguishing features. The Karacadag rice variety has medium kernel size. The high amount of protein and starch in the rice makes pilaf (traditional food) delicious. Because of these properties, it has value as breeding material. This variety is highly resistant to the cold snow waters of Karacadag; it has a stable yield potential. This variety is cultivated for centuries and it has been genetically clarified (Alp 2011).

Karacadag rice in terms of micro element concentration was determined to be lower than WHO and Turkish standard institution permissible limits and, therefore, was found safe for public consumption (Duzgun et al. 2018). Recently, with the introduction of the advanced technologybased farming and introduction of highly productive varieties into the production areas, many of the local varieties have disappeared and many of them still disappearing. Continuity in crop production will only be possible with the protection of the wild and local varieties.

The Karacadag is one of the important plantation areas of the endemic and rare crops as well as wild relatives of many Poaceae and Leguminous plants. The part of the Karacadag in the direction of the Diyarbakır which is spreaded over an area of approximately $7.200 \mathrm{~km}^{2}$ is suitable for plant production (Alp 2011). With this view in mind the present research work was undertaken to reveal the differences between the conventional and organic farming and to show the potentialities of local and breeding rice varieties in organic agricultural conditions. 


\section{Materials and Methods}

The present work was conducted to determine the potentialities of organic rice cultivation in Diyarbakır region and to set an example for farmers in transition to organic farming. The local Karacadag rice and Osmancık-97 breeding variety, the most cultivated variety in the Turkey were used in the research a test material. The research was carried out in 3 replications according to the split parcel trial design in random blocks in the 2012-13 rice growing periods in the experimental field of the GAP International Agricultural Research and Training Centre.

Karacadag local rice variety is a late flowering and its vegetative period is about 130 days, it is also resistant to cold and drought. It has poor resistance to lodging, it is tall and stringy. The Osmancik-97 rice variety is an Italian origin. Its sturdy is handle, and it is resistant to inclination. The structure of the variety is without strings and it does not spill its kernels.

Practice and application area of the GAP International Agricultural Research and Training Centre where the research was conducted is a first-class irrigable land. It has been observed that the habitat is clayey soil with humus-rich with $1-2 \%$ variation of slope. The soil samples collected at $0-20 \mathrm{~cm}$ depth were analysed and the results were: the water saturation rate of the soil samples was $87 \%$, total salt concentration was $0.013 \%$ in organic parcels, $0.014 \%$ in conventional parcels; soil pH was 7.94 in organic parcels, 7.85 in conventional parcels; the ratio of phosphorus from the useful nutrients from the plants was 12.1 in organic parcels, $17.7 \mathrm{~kg} / \mathrm{ha}$ in conventional parcels; the organic matter was $1.17 \%$ in organic parcels, $1.25 \%$ in conventional parcels.

The research site is located on $37^{\circ} 30$ ' and $38^{\circ} 43^{\prime}$. North latitudes and $40^{\circ} 37$ ' and $41^{\circ} 20^{\prime}$ east longitudes; the location is approximately 600 metres above the sea level. In the province of Diyarbakır where the field experiments are conducted the annual rainfall is mostly happened between October and May and very rare in the summer months. The proportional humidity rate is quite low. The annual average rainfall of the zone is $488.1 \mathrm{~mm}$, the relative humidity is $53 \%$ and the average temperature is around $15.8^{\circ} \mathrm{C}$.

In the autumn $15-20 \mathrm{~cm}$, in the spring $10-12 \mathrm{~cm}$ deep soil was processed and for the levelling of the land rollers and harrows were used. The main irrigation canal from the highest point of the field and the main drainage channel from the lowest point were used to create water distribution channels in the field. The size of the parcel was set on $15 \mathrm{~m}^{2}(3 \times 5 \mathrm{~m})$ and $10.0 \mathrm{~m}^{2}$ $(2.5 \times 4.0 \mathrm{~m})$ at harvest.

Pre-germinated seeds were planted in the water $10-15 \mathrm{~cm}$ deep as 500 units for per square $\mathrm{m}$ for conventional parcels and 550 units for organic parcels with the broadcast sowing method on 03.05.2012 and 24.05.2013.

In the conventional rice parcels, $150 \mathrm{~kg} / \mathrm{ha}$ nitrogen and $60 \mathrm{~kg} / \mathrm{ha}$ phosphorus were used. One third of the nitrogen and all of the phosphorus were applied at the same time with planting. The second one third of the nitrogen was applied during the tillering and the last one third was given as sprinkles before the earing period.

The Kirazlı forage pea was planted in the organic rice parcels without any fertilizer or pesticide for the purpose of providing green fertilizer. At the half stage of the flowering period (50\%), the yield of weed grass was measured as $14300 \mathrm{~kg} / \mathrm{ha}$ in 2012 and $13800 \mathrm{~kg} / \mathrm{ha}$ in 2013; and it was shattered with rotary tiller and mixed with soil. In addition, the solid fertilizer was planted at $1.4 \mathrm{t} / \mathrm{ha}$ and half the B5A liquid organic fertilizer $(4 \mathrm{~kg} / \mathrm{ha}$ ) was used at the planting site. The other half of the liquid organic fertilizer was given one month before harvesting through the leaves. Chemical weedicides were applied against wild weeds in conventional rice parcels while weeds in organic parcels were picked by hand. 
Irrigation water was supplied from underground water extracted from the depth of 200 meters during the installation phase. In the period up to the harvest, the irrigation was interrupted before the weed struggle, and irrigation was interrupted 10 to 15 days before full ripening to ensure the dryness of the harvested fields. The harvesting took place on 05.10.2012-04.10.2013 when the rice plants turn yellow and bunches dangled from trunks.

Number of days of flowering, days of maturation, plant height $(\mathrm{cm})$, number of tillering in plants, kernel number of a bunch, kernel weight of a bunch $(\mathrm{g}), 1000$-kernel weight $(\mathrm{g})$, length of the bunch $(\mathrm{cm})$, biological yield $(\mathrm{kg} / \mathrm{ha})$, unit area kernel weight $(\mathrm{kg} / \mathrm{ha})$, and non-fractured rice yield $(\%)$ were measured and the data obtained from the study were analysed in the JUMP statistical package program. The LSD test was applied and the coefficient of variation (CV) was calculated with the differences between the averages (Yurtsever 1984, Düzgüneş et al. 1987).

\section{Results and Discussion}

When the average values of varieties examined in terms of number of days of flowering, the differences between rice varieties and applications are statistically significant at 1\%; 82.8 days in conventional conditions, 87.3 days in organic condition for Karacadag variety; 75.2 days in conventional conditions and 77.8 days in organic conditions for Osmanc1k-97 variety. The average values of the varieties with regards to the growing conditions were 79.0 days in conventional farming and 82.6 days in organic farming (Table 1). Kıran (1992) found that the number of days of flowering in Diyarbakır was between 64 and 118 days. Şavşatlı and Gülümser (2006) stated that in the ecological conditions of Samsun, the number of days of flowering rice changes between 79 and 89 days with the broadcast seeding method according to the variety used.

The average number of maturity days of Karacadag variety was 128.5 in conventional condition, 128.2 days in organic conditions; Osmancık-97 variety was 115.7 days in conventional conditions and 116.0 days in organic conditions. The average values of the varieties were found to be 122.1 days both in organic and conventional practises (Table 1). Şavşatlı and Gülümser (2006) stated that the number of ripening days in rice is between 120 and 136 days with the help of broadcast seeding method among the varieties used. Kıran (1992) reported it to range between 96 and 143 days in Diyarbakır conditions. Gençtan et al. (1994) reported it to vary between 119 and 143 days in a research conducted on a total of 10 different rice varieties.

The average plant height of local Karacadag variety was $105.5 \mathrm{~cm}$ in conventional conditions and $84.1 \mathrm{~cm}$ in organic conditions; Osmanc1k-97 was $89.9 \mathrm{~cm}$ in conventional conditions and 66.7 $\mathrm{cm}$ in organic conditions. It may be concluded that the average values of the varieties were 75.4 $\mathrm{cm}$ in organic application and $97.7 \mathrm{~cm}$ in conventional application (Table 1). Karacadag local variety showed longer plant height in both conventional and organic conditions than Osmancik-97 variety. The plant height affecting rice farming indirectly depends on the level of fertility of the soil, the method of sowing, the amount of applied fertilizer, environmental conditions and the genetic structure of the variety. Alp et al. (2010) stated that plant height of rice farming in the conditions of Diyarbakır changes between $81.82-99.50 \mathrm{~cm}$.Taşer (2011) stated that the average plant height varied between 67.5 and $110.3 \mathrm{~cm}$ in the south-east Anatolia region and Karacadag local rice variety is longer than any other variety.

When the average values of the varieties examined with regards to the number of tillering in plants the local Karacadag variety was 3.48 and the Osmancik-97 was 2.60 in conventional conditions whereas it was 2.82 and 2.22 in organic conditions. The average values of the varieties were 2.52 in organic application and 3.04 in conventional application (Table 1). It has been observed that the local Karacadag rice variety was more abundant in terms of tillering in both the farming conditions than the Osmanckk-97 variety. The number of tillering in plants depends on the 
genetic characteristics of the varieties and it is greatly influenced by the environmental conditions (Kün 1988). Lin (1974) stated that the number of tillering per plant decreased when the rice planted frequently in the field, and the companions that formed after the maximum period of tillering decreased because of their inability to complete their development. Gevrek (2000) pointed out that the average number of tillering between applications in the rice plants at Menemen's ecological conditions varied between 1.3 and 2.9. On the other hand Alp et al. (2010) stated that the number of tillering formed in rice in Diyarbakır conditions changes between $5.03-10.47$.

Table 1. Average values of number of days of flowering, number of ripening days, plant height, number of tillering of Karacadag and Osmancik-97 varieties grown in conventional and organic agricultural conditions.

\begin{tabular}{llcccc}
\hline $\begin{array}{l}\text { Growing } \\
\text { condition }\end{array}$ & $\begin{array}{l}\text { Name of } \\
\text { varieties }\end{array}$ & $\begin{array}{l}\text { No. of days } \\
\text { of flowering }\end{array}$ & $\begin{array}{l}\text { No. of days } \\
\text { of ripening }\end{array}$ & $\begin{array}{l}\text { Average plant } \\
\text { height }(\mathrm{cm})\end{array}$ & $\begin{array}{l}\text { No. of } \\
\text { tillering }\end{array}$ \\
\hline Conventional & Karacadag & $82.8 \mathrm{~B}$ & 128.5 & 105.5 & 3.48 \\
& Osmancik-97 & $75.2 \mathrm{D}$ & 115.7 & 89.9 & 2.60 \\
& Average & 79.0 & 122.1 & 97.7 & 3.04 \\
Organic & Karacadag & $87.3 \mathrm{~A}$ & 128.2 & 84.1 & 2.82 \\
& Osmancik-97 & $77.8 \mathrm{C}$ & 116.0 & 66.7 & 2.22 \\
& Average & 82.6 & 122.1 & 75.4 & 2.52 \\
CV $(\%)$ & & 0.25 & 0.37 & 2.89 & 8.47 \\
\hline
\end{tabular}

*The difference between the averages shown with the same letter does not important at 0.05.

Table 2 shows that the number of bunches per $\mathrm{m}^{2}$ of local Karacadag variety was 362.3 and 369.3 in conventional and the organic conditions, respectively and of Osmancik-97 variety was 318.0 and 251.8 in conventional and organic conditions, respectively. The average values of the varieties were 310.5 and 340.2 in organic and conventional application, respectively. It was observed that the local Karacadag rice variety yielded a larger number of bunches than the Osmancik-97 variety in both conventional and organic conditions.

Choi et al. (2002) stated that the number of bunches per $\mathrm{m}^{2}$ was 364 in conventional application and in organic application it was 420 - 444. Kiran and Oktar (1994) observed the number of bunches in $\mathrm{m}^{2}$ which varied between 372 and 639 in Diyarbakır conditions and the number of bunches in $\mathrm{m}^{2}$ of Karacadag variety was higher than other varieties and lines.

Table 2 also revealed that kernel number of bunch, of the Karacadag variety was 76.1 and 56.5 in conventional and organic conditions, respectively the Osmancık-97 was 75.9 and 54.1 in conventional and organic conditions, respectively. It may be concluded that in terms of breeding conditions the average number of kernel in bunch was 55.3 in organic conditions and 76.0 in conventional conditions. The kernel number of bunch in organic conditions was low in both the varieties against conventional conditions.

In the southeast Anatolia region rice populations exposed to temperatures over 40 degrees at the flowering period may cause spikelet infertility, but Karacadag variety is less affected by temperature than other breeding varieties. These high temperature values caused more stress in the Osmancik-97 variety than Karacadag variety and it also caused a decrease in kernel number of the plant's bunch. 
Choi et al. (2002) also found that the kernel number of bunches was 79.6 - 88.0. Kuran and Oktar (1994) observed that it varied between 52 and 147 with Diyarbakır conditions. Alp et al. (2010) stated that the kernel number of bunches in rice farming varies 42.08 - 99.50 with Diyarbakır conditions. Şahin et al. (2012) determined the kernel number of bunches 43.6 - 113.1. Taşer (2011) stated that the kernel number of bunches changes between 89.33 and 164.0 and the values of local rice samples was higher than those of many breeding varieties with regards to the kernel number of bunches. The average kernel weight of bunch of the local Karacadag variety is $2.22 \mathrm{~g}$ in conventional conditions, $1.73 \mathrm{~g}$ in organic conditions; Osmanc1k-97 variety was $2.37 \mathrm{~g}$ in conventional conditions and $1.73 \mathrm{~g}$ in organic conditions. In terms of growing conditions, the average kernel weight of bunch was $1.73 \mathrm{~g}$ in organic conditions and $2.29 \mathrm{~g}$ in conventional conditions (Table 2). The kernel weight of bunch in organic conditions was low in both the varieties against conventional conditions. Alp et al. (2010) stated that the kernel weight of bunch varies $1.22-2.69 \mathrm{~g}$ in Diyarbakır conditions. Taşer (2011) stated that the kernel weight of bunch varies 1.463-1.942 $\mathrm{g}$ under the conditions of the south-east Anatolian Region. The average values of the varieties related to the 1000-kernel weight of the local Karacadag variety was $29.02 \mathrm{~g}$ in conventional conditions and $30.59 \mathrm{~g}$ in organic conditions; the Osmancık-97 variety was $31.38 \mathrm{~g}$ in conventional conditions and $32.17 \mathrm{~g}$ in organic conditions. In terms of growing conditions, the average 1000-kernel weight of varieties was determined as $31.38 \mathrm{~g}$ in organic application and $30.20 \mathrm{~g}$ in conventional application (Table 2).

Table 2. The average values of bunch number in square meter, kernel number of bunch, kernel weight of bunch, 1000-kernel weight of Karacadag and Osmancik-97 varieties grown in conventional and organic agricultural conditions

\begin{tabular}{llllll}
\hline $\begin{array}{l}\text { Growing } \\
\text { condition }\end{array}$ & $\begin{array}{l}\text { Rice } \\
\text { varieties }\end{array}$ & $\begin{array}{l}\text { No. of bunch } \\
\text { per in } \mathrm{m}^{2}\end{array}$ & $\begin{array}{l}\text { No. of kernel } \\
\text { per bunch }\end{array}$ & $\begin{array}{l}\text { No. of kernel wt. } \\
\text { per bunch }(\mathrm{g})\end{array}$ & $\begin{array}{l}\text { No. of } \\
\text { 1000-kernel }(\mathrm{g})\end{array}$ \\
\hline Conventional & Karacadag & 362.3 A & 76.1 & 2.22 & 29.02 \\
& Osmancik-97 & $318.0 \mathrm{~B}$ & 75.9 & 2.37 & 31.38 \\
& Average & 340.2 & 76.0 & 2.29 & 30.20 \\
Organic & Karacadag & $369.3 \mathrm{~A}$ & 56.5 & 1.73 & 30.59 \\
& Osmancik-97 & $251.8 \mathrm{C}$ & 54.1 & 1.73 & 32.17 \\
& Average & 310.5 & 55.3 & 1.73 & 31.38 \\
$\mathrm{CV}(\%)$ & & 4.59 & 8.56 & 7.36 & 2.97 \\
\hline
\end{tabular}

*The difference between the averages shown with the same letter does not important at 0.05.

The average bunch length of the local Karacadag variety was $17.5 \mathrm{~cm}$ in conventional conditions and $15.9 \mathrm{~cm}$ in organic conditions; the Osmanc1k-97 was $13.2 \mathrm{~cm}$ in conventional conditions and $11.8 \mathrm{~cm}$ in organic conditions. In terms of growing conditions, the average values of bunch lengths of the varieties were $13.8 \mathrm{~cm}$ in organic applications and $15.3 \mathrm{~cm}$ in conventional application (Table 3). It was observed that the local Karacadag variety showed higher values with regards to bunch length compared to the varieties in both growing conditions. Tasser (2011) determined that the bunch length changes between 12.40 and $23.20 \mathrm{~cm}$, the bunch length of Osmancik-97 variety was $14.17 \mathrm{~cm}$ and the average of Karacadag population lines was around $21.06 \mathrm{~cm}$. Şahin et al. (2012) observed that the bunch length varies between 11.7 and $18.5 \mathrm{~cm}$. 
Table 3 also shows that the biological yield of the local Karacadag variety was $16560 \mathrm{~kg} / \mathrm{ha}$ and $13442 \mathrm{~kg} / \mathrm{ha}$ conventional and organic conditions, respectively. The Osmanc1k-97 variety was $11708 \mathrm{~kg} / \mathrm{ha}$ and $8657 \mathrm{~kg} / \mathrm{ha}$ in conventional organic conditions, respectively. In terms of growing conditions, the average values of the biological yields of the varieties were $11049 \mathrm{~kg} / \mathrm{ha}$ and 14134 $\mathrm{kg} / \mathrm{ha}$ in organic and conventional application, respectively. It has been observed that the local Karacadag variety has a significant superiority over the Osmancik-97 variety with regards to the biological yield in both conventional and organic conditions. It was also observed that biological yield decreases significantly under organic conditions.

The average values of kernel yield in unit area of the local Karacadag variety was $5074 \mathrm{~kg} / \mathrm{ha}$ and $4681 \mathrm{~kg} / \mathrm{ha}$ in conventional and organic conditions, respectively. The Osmanc1k-97 variety was $4288 \mathrm{~kg} / \mathrm{ha}$ and $2360 \mathrm{~kg} / \mathrm{ha}$ in conventional organic conditions, respectively. In terms of growing conditions, the average kernel yield in unit area was $3521 \mathrm{~kg} / \mathrm{ha}$ in organic application and $4681 \mathrm{~kg} / \mathrm{ha}$ in conventional application (Table 3). It has been observed that the local Karacadag variety has a distinctive superiority with regards to the kernel yield in unit area compared to the Osmancik-97 variety in both conventional and organic conditions. It can be said that the Osmancik-97 variety showed a lower kernel yield in unit area than the local Karacadag variety. This might be due to the fact that the ripening period corresponds to high temperatures and it does not adjust to the Diyarbakır's ecological environment. Choi et al. (2002) found out the kernel yield of the hairy vetch was $5680-5870 \mathrm{~kg} / \mathrm{ha}$ in organic conditions and $5760 \mathrm{~kg} / \mathrm{ha}$ in conventional conditions. They also stated that in farmyard manure application, the kernel yield was $5340-6660 \mathrm{~kg} / \mathrm{ha}$ in organic conditions and $6210 \mathrm{~kg} / \mathrm{ha}$ in conventional application. They pointed out that farmyard manure can be used in the production of hairy vetch. In an organic research conducted Lee et al. (2004) stated that the application of $100 \mathrm{~kg}$ nitrogen and $30 \mathrm{~kg}$ phosphorus per hectare yielded the highest number of yield with $5690 \mathrm{~kg} / \mathrm{ha}, 20$ tons of hairy vetch application for hectare yielded $5290 \mathrm{~kg} / \mathrm{ha}, 12$ tons compost application for hectare yielded with $4380 \mathrm{~kg} / \mathrm{ha}$. In a research conducted, Abu Bakar et al. (2003) reported that they achieved a yield of $1760-4100 \mathrm{~kg} / \mathrm{ha}$ with organic applications, the average yield value obtained was 3200 $\mathrm{kg} / \mathrm{ha}$, and the rice yield in the region was around $5000 \mathrm{~kg} / \mathrm{ha}$. Beşer and Gençtan (1999) stated that the yields of rice vary according to the ecological conditions, variety and technology used.

In the present research when the average values of varieties examined with regards to the nonfractured rice yield it was found that the local Karacadag variety was 65.5 and $64.7 \%$ in conventional and organic conditions, respectively. The Osmanc1k-97 variety was 55.8 and 58.8\% in conventional and organic conditions, respectively. The average non-fractured rice yield of the varieties in terms of growing conditions were found to be 61.7 and $60.6 \%$ in organic and conventional application, respectively (Table 3 ). It has been observed that the local Karacadag variety has a significant superiority over the Osmancik-97 variety both in conventional and organic conditions. It has also been observed that the kernel size of the local Karacadag variety was medium and the fracture rate during rice processing is rather low. It was observed that varieties grown in organic conditions had higher rice yield values.

Şavşatlı and Gülümser (2006) stated that the factors affecting the rice yield are kernel length, kernel shape and 1000-kernel weight; for instance K-424 rice variety was shorter and fuller than the other varieties which lead the variety to have high rates of fractured and non-fractured rice yield. Therefore, they expressed that the genetic properties of the varieties affect rice yield to a great extent. Taşer (2011) stated that the yield values of rice samples varied between 51.67 and $68.67 \%$ in the conditions of the south-east Anatolian region, and the highest non-fractured rice yield was found in the samples of the local Karacadag rice variety.

As a result of agricultural research, organic and conventional applications; organic application showed higher values compared to the conventional application with regards to the number of 
days of flowering, 1000-kernel weight and non-fractured rice yield. It was observed that the number of ripening days was equal in both the growing conditions. However, it was observed that following values fell behind in organic conditions compared to the conventional conditions: plant height, number of tillering, bunch number in $\mathrm{m}^{2}$, kernel number of bunch, kernel weight of bunch, bunch length, biological yield and kernel yield in unit area.

Table 3. The average values of bunch length, biological yield, kernel yield in unit area, non-fractured rice yield of Karacadag and Osmancik-97 varieties grown in conventional and organic agricultural conditions

\begin{tabular}{llllll}
\hline $\begin{array}{l}\text { Growing } \\
\text { condition }\end{array}$ & $\begin{array}{l}\text { Rice } \\
\text { varieties }\end{array}$ & $\begin{array}{l}\text { Bunch length } \\
(\mathrm{cm})\end{array}$ & $\begin{array}{l}\text { Biological yield } \\
(\mathrm{kg} / \mathrm{ha})\end{array}$ & $\begin{array}{l}\text { Kernel yield in } \\
\text { unit area }(\mathrm{kg} / \mathrm{ha})\end{array}$ & $\begin{array}{l}\text { Non-fractured } \\
\text { rice yield (\%) }\end{array}$ \\
\hline Conventional & Karacadag & 17.5 & 16560 & $5074 \mathrm{~A}$ & $65.5 \mathrm{~A}$ \\
& Osmancik-97 & 13.2 & 11708 & $4288 \mathrm{C}$ & $55.8 \mathrm{C}$ \\
& Average & 15.3 & 14134 & 4681 & 60.6 \\
Organic & Karacadag & 15.9 & 13442 & $4681 \mathrm{~B}$ & $64.7 \mathrm{~A}$ \\
& Osmancik-97 & 11.8 & 8657 & $2360 \mathrm{D}$ & $58.8 \mathrm{~B}$ \\
& Average & 13.8 & 11049 & 3521 & 61.7 \\
$\mathrm{CV}(\%)$ & & 4.72 & 3.54 & 4.66 & 1.57 \\
\hline
\end{tabular}

*The difference between the averages shown with the same letter does not important (N.I.) at 0.05.

The local Karacadag rice variety cultivated in conventional conditions showed superior values than the Osmancik-97 variety in terms of number of days of flowering, number of ripening days, plant height, number of tillering in plants, bunch number in $\mathrm{m}^{2}$, kernel number in bunch, bunch length, biological yield, kernel yield in unit area, and non-fractured rice yield. However, it was observed that the local Karacadag variety fell behind to the Osmancik-97 variety with the regards to the kernel weight of bunch and 1000-kernel weight.

The local Karacadag rice variety cultivated in organic conditions showed superior values than the Osmanc1k-97 variety in terms of number of days of flowering, number of ripening days, plant height, potential of tillering, bunch number in a square meter, kernel number of bunch, bunch length, biological yield, kernel yield in unit area and non-fractured rice yield. However, in organic conditions the local Karacadag variety fell behind to the Osmancik-97 variety with regards to the thousand kernel weight. It was determined that both the varieties showed equal values in kernel weight of bunch. It is concluded that the use of Karacadag variety in organic agriculture may extend the organic agriculture in the region.

The Karacadag variety is a sensitive to inclination because it is a tall variety. During the trial the inclination move of the Osmancik-97 variety was not seen. In the years when the research was carried out, the rate of inclination of the Karacadag variety in organic parcels slightly decreased compared to the conventional parcels. As the Osmancik-97 variety made a less number of tillering, its competition with weed was weaker and the weed rate was higher. In organic parcels, the amount of weed was higher because the plants made a less number of tillering.

The flowering phase is more sensitive to high temperatures is the flowering phase. In the flowering phase, when the maximum daily temperature is over $35^{\circ} \mathrm{C}$, ear infertility increases. The most suitable sowing time for the Diyarbakır is between the $20^{\text {th }}$ of April and $5^{\text {th }}$ of May. Due to the delay in sowing, the flowering periods of the rice varieties corresponded to high temperatures 
$\left(35-41^{\circ} \mathrm{C}\right)$. Since the kernel number in a bunch is negatively affected by the high temperature, the kernel number in bunch was low. A low number of kernels in bunch resulted in low kernel yield in unit area. However, the Karacadag variety was less affected by the higher temperatures.

When all the features examined in the research taken into consideration in addition to many features of the Karacadag variety, it was observed that the kernel yield in unit area was highest at $5074 \mathrm{~kg} / \mathrm{ha}$ in the conventional application while the organic application of the Karacadag variety was in second place with $4681 \mathrm{~kg} / \mathrm{ha}$. It is concluded that the organic rice farming is thought to be economical when it is considered that the organic rice in the market sold with about $30 \%$ more the price compared to the conventional rice.

\section{Acknowledgements}

This work was supported by a grant from Republic of Turkey Ministry of Food, Agriculture and Livestock (Project No: TAGEM/TA/11/07/03/005).

\section{References}

Abu Bakar AR, Yon R, Abdullah S, Zakaria A, Omar O, Malik Z, Othman S and Azmiman 2003. Conversion of Kampong rice fields in Langkavi, Malaysia, into organic rice farming. Source: [http://www.regional. org.au ]. Access Date: 18.11.2010.

Alp A, Yeşilmen S, Vural A and Güran Ş 2010. Determination of some agronomical characteristics and Ochratoxin-A level of Karacadag rice (Oryzasativa L.) in Diyarbakir ecological conditions, Turkey. African Journal of Agricultural Research 4(15): 1965-1972.

Alp A 2011. Paddy. Sector Analysis. Sectoral Development Plan in Rural Area of Karacadag. A Research for Micro Region Development Model. Diyarbakır, pp. 60-84.

Altındişli A and İlter E 1999. Principles and Concepts in Eco-Agriculture.Ecological Agriculture. ETO Ecological Agriculture Education Course Notes, İzmir.

Anonymous 2017. Rice Productions, The Food and Agriculture Organization of the United Nations (FAO), Source: [www.faostat.fao.org]. Access Date: 29.09.2019.

Anonymous 2015. Turkish Statistical Institute. Agriculture/Crop Production Statistics. Source: [http://www. tuik.gov.tr/VeriBilgi.do?tb_id=45\&ust_id=13]. Access Date: 31.08. 2017.

Beşer N and Gençtan T 1999. Effect of different sowing methods in rice (Oryzasative L) yield and some agricultural characteristics in Trakya region. Turkey's $3^{\text {rd }}$ Field Crops Congress, Adana. pp. 462-467.

Choi D, Goh HG and Lee YJ 2002. The Modern Technique for Organic Rice Cultivation in Korea. RDN/ARNOA İnternational Conference 'Development of Basic Standard for Organic Rice Cultivation' 12-15 November 2002. RDA and Dankook University, South Korea, pp. 286-306.

Duzgun M., Baran F.B., Kahraman Ş., Duz M.Z., 2018. Determınatıon of trace elements in Karacadag rice by 1 cp-oes. Internationa Engineering and Natural Sciences Conference. S, 525-533, Diyarbakır.

Demiryürek K 2004. Organic agriculture in the world and the Turkey. Journal of Agriculture Faculty of Harran University 8(3-4), Şanlıurfa.

Düzgüneş O, Kesici T, Kavuncu O, andMorrone F 1987. Research and Trial Methods (Statistical Methods II) Ankara University Faculty of Agriculture. Publication No: 1021, pp. 381, Ankara.

Gençtan T, İlhami ÖA, Başer İ, 1994. Determination of RelationBetween Paddy Yield and Some Yield Components in Paddy by Path Analysis. Bursa, (1-2): pp. 158-165.

Gevrek NG 2000. A research on the use of azolane as nitrogen source in paddy farming. Turk J. Agric. For 24 pp. 165-172, (C) TÜBITAK.

Gürsoy S, Türk Z, İkinci İ and Kolay B 2009. Organic Farming Perspective of Farmers in Diyarbakır Province and its Regions. 1st GAP Organic Agriculture Congress.17-20 November 2009, Şanlıurfa. pp. 254-259. 
İnci T, and Sönmez K 2006. Mineral Element Content of Plant Products Obtained In Organic Agriculture and Conventional Agriculture and Evaluation of the Level of Various Compounds. $3^{\text {rd }}$ Organic Agriculture Symposium, 1-3 November, 2006. Yalova. pp. 80.

Kiran A 1992. Result Report of Paddy Sowing Time Determination Trial. Southeast Anatolia Agricultural Research Institute Publications. Publication No. 1992/6, pp. 23-34. Diyarbakır.

Kiran A and Oktar F 1994. The 1993 Development Report, National Paddy Researches, pp. 106-118. Diyarbakır.

Kün E 1988. Summer Growing Cereals.Ankara University Faculty of Agriculture. Publication No. 1032, Ankara.

Lee YH, Lee SM, LeeYJ and Choi DH 2004. Rice cultivation using organic farming system with organic input materials in Korea National Institute of Agricultural Science and Technology, Suwon 441-707, South-Korea.

Lin MH 1974. Studies on the relation among leaf age index, the stages of panicle development under different conditions in rice.Bull. Taichung Dis. Agr. Imp. Sta. 10: 1-22.

Şahin M, Sezer İ, Dengiz O, Akay H and Öner F 2012. Determination of Yield Performance of Some Paddy Cultivars Grown in Kizılirmak Conditions. Journal of Agricultural Sciences Research 5: 33-36.

Şavsatli Y and Gülümser A 2006. The Effects of Plant Seedling and Broadcast Seeding Methods on Yield and Quality Characteristics of Some Paddy Cultivars, OMÜ Faculty of Agriculture Journal, 2006, 21(2): 154-159.

Taşer E 2011. Comparison of Agricultural and Quality Characters of Local Karacadag Paddy with Some Breeding Varieties in the Southeast Anatolian Region Conditions. Postgraduate Thesis, Dicle University.Institute of Science and Technology, Diyarbakır.

Willer H and Klicher L (ed) 2011. The World of Organic Agriculture. Statistics and Emerging Trends 2011.FiBL-IFOAM Report. IFOAM, Bonn and FiBL, Frick.

Yurtsever N 1984. Experimental Statistical Methods. Ministry of Agriculture and Rural Affairs General Directorate Publication. 